\title{
Shift of the EU Energy Policy and China's Strategic Opportunity
}

Maximilian Mayer

and Susanne Peters

\begin{abstract}
The core idea of the European Union (EU) is to foster economic and political integration among its member states based on liberal principles, a common market, and the establishment of a business-friendly environment. What is surprising is the new rhetoric originating in Brussels and connected to the "Energy Union" that portrays its energy dependence on Russia as a potential threat. One important dimension of this newly launched "Energy Union" is the replacement of the EU's market orientation in its energy relations with Russia by a "securitization" of Russia's intention vis-à-vis Europe. These securitizing moves culminate in a vigorous and costly diversification strategy for natural gas supply. The construction of new liquefied natural gas (LNG) terminals and gas storage, as well as a new gas mega pipeline passing through Central Asia is part of this new strategy. The recently inaugurated "Energy Union," at the same time, includes improved infrastructure connections and the approval of domestically produced shale gas. As a result, natural gas has gained the
\end{abstract}

Maximilian Mayer is Research Professor at the German Studies Center of Tongji University. He can be reached at maximilian_mayer@tongji.edu.cn. Susanne Peters is a visiting fellow at the German Studies Center, Tongji University, and Senior Research Fellow at Webster University, Geneva, Switzerland. She can be reached at peters@webster.ch. Their mailing address is Room 908, CD-Building, Tongji University, 1239 Siping Road, Shanghai 200092, China.

(c) 2017 World Century Publishing Corporation and Shanghai Institutes for International Studies China Quarterly of International Strategic Studies, Vol. 3, No. 1, 137-158

DOI: $10.1142 / S 2377740017500051$ 
status of a "bridge fuel" while related large-scale infrastructure would lock European economies into a fossil path that ultimately undermines the EU's goal toward a decarbonized economy. Analyzing the European Commission's emphasis on natural gas, produced either by conventional or unconventional extraction methods, bears critical insights for China's energy strategy. As the EU appears to have shifted its emphasis from sustainability to energy security, a vacuum would be left for China to fill, thus rendering it eligible to play the role of the next global leader in climate politics.

Keywords: "Energy Union"; EU-Russia energy relations; securitization; shale gas; China's energy strategy.

Despite the severe crisis of its raison d'être caused by the influx of refugees and "Brexit," the European Union (EU) remains a significant player in international politics and an economic giant. While only comprising 6 percent of the world's population, it generates one fourth of the global gross domestic product (GDP), and uses more than 12 percent of the world's energy supply. ${ }^{1}$ Unlike China, the EU is neither a centralized, unified state nor a federal state with the power to act in all relevant domestic and foreign policy areas on behalf of European citizens and its member states. After several rounds of reform and expansion, the EU has developed into a "regulatory state" ${ }^{2}$ with the power to set up laws and regulations in many relevant policy areas. Even for sensitive issues concerning foreign, security, and energy policies, in which member states are reluctant to give up sovereignty, significant progress has been achieved in recent years, in particular with regard to energy. ${ }^{3}$

The EU's energy policy culminated in the launching of the Third Energy Package of 2009 and then establishment of the "Energy Union" in 2015. The European Commission made a decision to obtain the member

1“The EU in the World - Energy," Eurostat, http://ec.europa.eu/eurostat/statisticsexplained/index.php/The_EU_in_the_world_-_energy.

${ }^{2}$ Andreas Goldthau and Nick Sitter, "Soft Power with a Hard Edge: EU Policy Tools and Energy Security," Review of International Political Economy, Vol. 22, No. 5 (2015), pp. 941965.

${ }^{3}$ Richard Youngs, “The EU's Global Climate and Energy Policies: Gathering Momentum?," FRIDE Working Paper, April 18, 2013, http://fride.org/publication/1122/the-eu. 
states' mandate for all relevant energy matters concerning energy affordability, sustainability, and supply security. With a large portion of its primary energy being imported by Russia, and a record of supply crisis with Russia, EU-Russia energy relations took center stage within the EU's current energy policy considerations.

In the past two years, the European Commission has started redrafting the EU's energy policy, with considerable consequences for both sustainability and climate goals, as well as Europe's foreign relations. The EU's de facto renunciation of its role as a climate action leader began in October 2014, when the EU scaled back its long-term goals to reduce global warming and proposed "less-ambitious targets" for emissions, efficiency, and renewables. ${ }^{4}$ For international relations scholars and observers of the EU, this shift represents an interesting puzzle. Why would the EU, de facto, give up its aspirations to be the world's climate leader? What is the reason that natural gas is becoming a "bridge fuel" that determines the long-term orientation of Europe's energy supply? Based on a variety of sources, we argue that the intensifying conflict between the EU and Russia and the securitization of EU-Russia natural gas relations in particular, became a catalyst to fostering a vigorous diversification strategy for the EU, possibly paving the way for domestically produced shale gas, and locking in natural gas for decades. The reshaping of the EU's energy policy has created significant implications for China, since the country is determined to restructure its energy mix and committed to fulfilling the Paris Agreement on climate change that took effect on November 4, 2016.

\section{The EU's Energy Policy Update: Prioritizing Security Over Sustainability}

Energy policy inevitably faces a "trilemma." It encapsulates three dimensions that are not always complementary, but have the potential to neutralize each other: the traditional component of security of supply, energy equity (which means affordability and competitiveness), and

\footnotetext{
${ }^{4}$ Alexander Bürgin, “National Binding Renewable Energy Targets for 2020, But Not for 2030 Anymore: Why the European Commission Developed from a Supporter to a Brakeman," Journal of European Public Policy, Vol. 22, No. 5 (2015), pp. 690-707.
} 
environmental sustainability. ${ }^{5}$ From 2008 to 2013 the focus of the EU's energy policy was undoubtedly on the third dimension, as seen in the launching of the 2009 "Climate and Energy Package" enshrining climate targets for 2020, as well as the 2011 creation of the 2050 roadmap, which aims at de-carbonization of $\mathrm{CO}_{2}$ greenhouse gas by at least 80 percent. ${ }^{6}$ But it seems that EU decision-makers have recently decided to de-emphasize the original goal of environmental sustainability and effective climate policy and begun to pursue an energy policy that is increasingly prioritizing energy security and competitiveness at the expense of sustainability.

The first reason for this shift is related to the costs for sustainability and the EU's growing concern that it might lose its competitiveness vis-à-vis its trading partners. While gas prices have decreased significantly over the last three years due to falling oil prices and oversupply caused by the U.S. shale gas revolution, EU gas prices are still twice as high

The EU is prioritizing energy security over environmental sustainability in its energy policy. as those of the United States. ${ }^{7}$ The relatively high gas price in the EU corresponds to the much lower price level of U.S. gas markets that are flooded by domestic shale gas production. The International Energy Agency (IEA) warned, “...that the EU share in the global export market for energy-intensive goods, especially for chemicals, is expected to fall (by around 10 percent across all energy intensive goods...) ...while the United States and emerging economies are expected to be able to increase their shares in the export markets." ${ }^{8}$ This is of relevance for the

${ }^{5}$ Albert Bressand, “The Changed Geopolitics of Energy and Climate and the Challenge for Europe," CIEP Paper, 2012, p. 7.

${ }^{6}$ Michael Huebler and Andreas Loeschel, "The EU Decarbonisation Roadmap 2050 What Way to Walk?," Energy Policy, Vol. 55, Issue C (2013), pp. 190-207.

${ }^{7}$ For prices of oil and natural gas, see the websites: https://ycharts.com/indicators/ natural_gas_spot_price; and https://ycharts.com/indicators/europe_natural_gas_price. See European Commission, A Framework Strategy for a Resilient Energy Union with a ForwardLooking Climate Change Policy, Communication from the Commission to the European Parliament, the Council, the European Economic and Social Committee, the Committee of the Regions and the European Investment Bank, 2015, p. 2.

${ }^{8}$ International Energy Agency, Energy Policies of IEA Countries, European Union, 2014 Review, 2014, p. 6. 
30 million people in the EU who work in heavy industries such as steel, iron, and petrochemicals. The IEA's Fatih Birol concludes that the ambitious climate change goals of the EU have wrongly been held responsible for the gas prices, while the main factor is the "high cost of imported energy."

Second, the EU has growing concerns about the security of its energy supply. Since domestic fossil fuel production is on a decline, the EU had to import 53.5 percent of its energy consumption in $2014 .^{10}$ Notably, natural gas dependence in the 28 member states of the EU was 67.4 percent and the EU imported about 37.5 percent of its gas needs in 2014 from Russia. ${ }^{11}$ The dependence rate of the individual EU member states is uneven: while several EU members do not get any Russian gas imports, Estonia, Finland, Latvia, Lithuania, Bulgaria, the Czech Republic, and Slovakia are almost entirely dependent on Russian energy imports. In this light, Gazprom plays the role of an energy monopolist, which often uses its monopolistic position for a "divide and rule" tactic, requesting its former satellites in the EU, i.e., the Central and Eastern European (CEE) countries, to pay higher prices for gas than the Western EU member states. Against this backdrop, several gas supply crises and the ongoing conflict between the EU and Russia over Ukraine have led to an ever-growing aversion against import dependence on Russian gas and oil and the elevation of energy security to a geopolitical priority for the EU. ${ }^{12}$

There are divergent forecasts of the size of the EU's future gas import demands. The IEA, in view of a further decline of domestic production, projects an increase in gas imports between 2020 and 2030, but in terms of

${ }^{9}$ Pilita Clark, “Energy Price Gap with the US to Hurt Europe for 'At Least 20 Years,"” Financial Times, January 29, 2014, https://www.ft.com/content/80950dfe-8901-11e3-9f4800144feab7de.

10“Energy Production and Imports,” Eurostat, http://ec.europa.eu/eurostat/statisticsexplained/index.php/Energy_production_and_imports.

${ }^{11} \mathrm{Ibid}$. There is plenty of gas in the world, but the problem is to have it locally available, a problem also called "tyranny of geography." Usually, gas is transported by pipelines; imported liquefied natural gas is an alternative to pipeline gas, but it requires special terminals for de-liquefying the gas again.

${ }^{12}$ Emil Kirchner and Can Berk, "European Energy Security Co-operation: Between Amity and Enmity," Journal of Common Market Studies, Vol. 48, No. 4 (2010), pp. 859-880. 
gas consumption a majority of prognoses forecast that it "will not rise dramatically up to 2030."13 The European Commission also seems optimistic that "further policies designed to achieve 2030 energy and climate targets may lead to a reduction in gas usage,"14 but does not specify how much. A realistic forecast is difficult at this moment since the import volume depends to a large extent on the future supply of renewable energy and further improvement of energy efficiency.

Until the mid-2000s the term "energy supply crisis" had been exclusively associated with oil and the various crises it triggered in the past, in particular the "oil crisis" of the 1970s. Gas was perceived as available in limitless quantities, and therefore the gas supply crises of 2006 and 2009 came as a distressing surprise. In both incidents, the EU was caught in a conflict, which actually was an upshot of strained Russian-Ukrainian relations. Ukraine and Russia had disputed about debts and the price for gas and as a consequence, Russia halted supply of gas to Ukraine. Deliveries to Europe were affected as well because the same pipelines are used for delivering gas to Ukraine and Europe. The 2009 conflict had dramatic consequences for the EU member states with a high dependence on Russian gas deliveries. The interruption lasted for two weeks in winter affecting 16 EU member states. Bulgaria and Slovakia did not have gas for several days and in Bulgaria, schools had to be closed. ${ }^{15}$

In 2014, the worsening of Russian-Ukrainian relations after the Russian annexation of Crimea triggered another incidence of Russia's interception of gas deliveries to Ukraine, and the EU, for the third time, was caught in the middle. But this time the EU mediated successfully between both partners and a severe gas shortage was prevented. These crises constitute the

${ }^{13}$ Shahrazad Far and Richard Youngs, "Energy Union and EU Global Strategy," SIEPS Report No. 5 (Stockholm: Swedish Institute for European Policy Studies, November 2015), p. 16, http://www.sieps.se/sites/default/files/sieps_\%202015_5_rapp.pdf.

${ }^{14}$ European Commission, “Liquefied Natural Gas and Gas Storage Will Boost EU's Energy Security," February 16, 2016, http://europa.eu/rapid/press-release_MEMO-16-310_en. htm.

${ }^{15}$ Adam N. Stulberg, "Out of Gas? Russia, Ukraine, Europe, and the Changing Geopolitics of Natural Gas," Problems of Post-Communism, Vol. 62, No. 2 (2015), pp. 112-130. See also Andreas Goldthau, "Addressing the Russian Energy Challenge: Why Regulations Trumps Geopolitics," GMF Policy Brief, December 2015, http://www.gmfus.org/publications/addressing-russian-energy-challenge-why-regulation-trumps-geopolitics. 
background for the EU's shift from sustainability to energy security and its determination to considerably reduce gas deliveries from Russia. ${ }^{16}$ Nevertheless, as we will argue in the following sections, supply problems with Russia are being politicized and even "securitized" and as a consequence of this act of securitization, a comprehensive diversification strategy compensating for future Russian gas deliveries is being advanced.

As one component of this diversification strategy, the EU approved the extraction of shale gas without any further effective regulatory framework. Furthermore, regardless of the volume of future demands for natural gas, new liquefied natural gas (LNG) terminals and a new gas pipeline will be built as compensation for the potential loss of Russian gas deliveries. Taken together, these diversification strategies are not environmentally sustainable and will lead to a fossil fuel lock-in for decades.

\section{Energy Union: A Mega Project to Address Supply Security}

In 2015, the EU responded to the perceived heightened gas import vulnerability by creating the European "Energy Union." Arguably, it is "the latest attempt to upgrade EU energy policy." ${ }^{17}$ Energy security is the focus of this mega project and there are several strategies devised to accomplish this goal. The most important strategy is to finally accomplish an internal energy market with the "[f]ull implementation and strict enforcement of existing energy and related legislation."18 The Energy Union also strives to establish "energy solidarity" between its member states and to set up some central decision-making capability on energy in the EU. The rationale behind this project is that if member states' gas pipelines have been interconnected with each other and gas can flow across borders without further physical hindrance, EU member states can assist each other in case of a supply crisis. Yet, in view of the current variance and incompatibilities of

${ }^{16}$ For an analysis of the impact of the crisis on Russian energy policies, see Alexander Gusev and Kirsten Westphal, "Russian Energy Policies Revisited," SWP Research Paper 2015/RP 08, December 2015, https://www.swp-berlin.org/fileadmin/contents/products/ research_papers/2015RP08_gsv_wep.pdf.

${ }^{17}$ Far and Youngs, "Energy Union and EU Global Strategy."

${ }^{18}$ European Commission, A Framework Strategy for a Resilient Energy Union with a Forward-Looking Climate Change Policy, p. 4. 
the EU member states' energy mix and infrastructure, the Energy Union amounts to a long-term project of enormous proportions.

Another strategic move is to overcome the dependence on Russia through diversification of gas delivery. This constitutes an escalatory policy toward Russia, because the mere suggestion of not keeping the contracts with Russia will substantially damage the long-term trade relationship between Russia and the EU. The EU seems to ignore that it is obliged to fulfill its contracts, which would, in turn, restrict a comprehensive diversification strategy. But it would be a surprise if the EU would indeed engage in this kind of unlawful behavior. The EU is rather expected to accept a potential future oversupply of natural gas for Europe.

The EU's gas demand is around 400 billion cubic meters (bcm) per year. The EU and Russia have agreed on gas contracts lasting until 2029, with a "take or pay volume" from $120 \mathrm{bcm}$ in 2017 to $70 \mathrm{bcm}$ in 2029. It is not imaginable that the EU will break its contracts with Russia. Legally, the EU has no other choice but to buy these quantities of gas. Negotiable are only 20 to $60 \mathrm{bcm}$ which are annually contracted volumes not included in the take-or-payment volumes. ${ }^{19}$ Even the EU admits that Russian pipeline gas is being contracted truly on a long-term basis and cannot be replaced with other kinds of contracts. ${ }^{20}$ Moreover, there is a whole pipeline system in place between Russia and Europe (Nordstream I through the Baltics, one transiting through Belarus and three crossing Ukraine). The planned doubling of the Nordstream gas capacity (Nordstream II) is also a strong indicator that the Russians are counting on European-Russian gas relations to continue in the future. ${ }^{21}$

Also, as scholars point out, Russian supplies are guaranteed, because there exists a pattern of interdependence between Russia and the EU.

${ }^{19}$ The numbers are based on the statistics released by CEDIGAZ - the international association for natural gas, NEXANT, the Russian Custom Service, and the Energy Research Institute of Russian Academy of Sciences.

${ }^{20}$ European Commission, “In-depth Study of European Energy Security,” May 28, 2014, http://register.consilium.europa.eu/doc/srv?l=EN\&f=ST\%2010409\%202014\%20ADD\%201, p. 9.

${ }^{21}$ It needs to be noted that the German-Russian project, which has not yet been canceled, faces serious difficulties in its realization. In the EU Commission the project does not find approval. See Karel Beckman, "Can Nordstream 2 be Stopped?," EnergyPost, April 14, 2016. 
Russia remained a reliable supplier of gas during the Cold War and even in the wake of the 1980 crisis of the Soviet occupation of Afghanistan. Moreover, Russia's pivot to Asia and the search for Asian customers has its limits - first, it will still take a while before the pipelines are in place; and second, the gas prices for the Chinese customers are lower than those for the Europeans. Furthermore, the 2009 supply interruption led to over \$1 billion in loss of export revenues for Russia. ${ }^{22}$ Obviously, Russia's dependence on energy revenues generated through the European gas trade is substantial. And most importantly, Russia needs Western technology for its declining oil and gas resources and in particular for the extraction of shale and off-shore gas.

\section{The EU tends to}

overstate the insecurity of Russian gas supply and politicize its energy relations with Russia.
Typically, the EU has stayed away from any politicization or geopolitics in its economic relations with other countries. But this market-oriented approach has been replaced recently by an active "securitization" of Russia's trade relations with the EU. ${ }^{23}$ Although rendering Russian energy supply to Europe into a security issue is a long-term process, ${ }^{24}$ it has progressively accelerated during the last two years at different levels. On the one hand, energy became fully securitized in the former Soviet states in Eastern Europe; yet on the other hand, top-level European politicians

${ }^{22}$ Stulberg, "Out of Gas? Russia, Ukraine, Europe, and the Changing Geopolitics of Natural Gas," p. 117.

${ }^{23}$ Ole Gunnar Austvik, "The Energy Union and Security-of-Gas-Supply," Energy Policy, Vol. 96 (2016), p. 380. See also Thomas Raines and Shane Tomlinson, "Europe's Energy Union: Foreign Policy Implications for Energy Security, Climate and Competitiveness," Chatham House Research Paper, March 2016, p. 2; and Far and Youngs, "Energy Union and EU Global Strategy," p. 2.

${ }^{24}$ Andrei Belyi, "New Dimensions of Energy Security of the Enlarging EU and Their Impact on Relations with Russia," Journal of European Integration, Vol. 25, No. 4 (2013), pp. 351-369; Maria Julia Trombetta, "Environmental Security and Climate Change: Analysing the Discourse," Cambridge Review of International Affairs, Vol. 21, No. 4 (2008), pp. 585602; and Petr Kratochvil and Lukas Tichy, “EU and Russian Discourse on Energy Relations," Energy Policy, Vol. 56 (2013), pp. 391-406. 
wanted to foster institutional and infrastructure integration of energy supplies through a security discourse. ${ }^{25}$

The notion of "securitization" is embedded in the epistemology and ontology of constructivism. A "securitization" is given if three criteria are fulfilled: (i) an actor through a "speech act" claims that a threat is existential; (ii) the threat implies the right to take extraordinary measures; and (iii) an audience is accepting that rules are broken, or allow to place "limitations on otherwise inviolable rights." ${ }^{26}$ The goal of an analysis of securitizing speech acts is not to establish whether the perception of this existential threat is right or wrong, because it is almost impossible to give "an objective measure of security." ${ }^{27}$ As the authors who developed this concept explain, "security rests neither with the objects nor with the subjects but among the subjects," thus it is inter-subjective, and not objectively measurable. It rather becomes consequential, reframing policy goals or measures as socially constructed, inter-subjective reality. ${ }^{28}$

Donald Tusk, then Polish Prime Minister and three months later President of the European Council, engaged in such a securitizing "speech act" when he was launching the Energy Union in April 2014 by arguing: "A united Europe can end Russia's energy stranglehold." ${ }^{29}$ The 2014 EU Energy Security Strategy explicitly refers to the 2006 and 2009 crises as a "wake up call," a strong reversal of Russia's role from being a strategic partner to an enemy to Europe with the role of a catalyst to draft this new energy security strategy: "[i]n the winters of 2006 and 2009, temporary disruptions of gas supplies strongly hit EU citizens in some of the eastern

${ }^{25}$ Tomas Janeliūnas and Agnija Tumkevič, "Securitization of the Energy Sectors in Estonia, Lithuania, Poland and Ukraine: Motives and Extraordinary Measures," Lithuanian Foreign Policy Review, Vol. 30 (2013), pp. 65-90; and Thomas Maltby, "European Union Energy Policy Integration: A Case of European Commission Policy Entrepreneurship and Increasing Supranationalism," Energy Policy, Vol. 55 (2013), pp. 435-444.

${ }^{26}$ Barry Buzan, Ole Waever, and Jaap de Wilde, Security: A New Framework for Analysis (Boulder, London: Lynne Rienner Publishers, 1998), p. 24.

${ }^{27}$ Ibid., p. 30.

${ }^{28}$ Ibid., p. 31.

${ }^{29}$ Donald Tusk, "A United Europe Can End Russia's Energy Stranglehold," Financial Times, April 21, 2014, https://www.ft.com/content/91508464-c661-11e3-ba0e-00144feabdc0. 
Member States. This was a stark 'wakeup call' pointing to the need for a common European energy policy." 30

Federica Mogherini, the EU High Representative, argued in a meeting with U.S. Secretary of State John Kerry in Washington in May 2016 in the context of the Energy Union, "that we have to prevent energy from being used as a political weapon, as we are very well aware that energy resources are still a major source of conflict." ${ }^{31}$ Miguel Arias Canete, the European Commissioner for Climate Change and Energy, remarked: "As you know energy security is one of the underlying planks of the Energy Union. And that's because we all remember the gas crises of 2006 and 2009 that left many millions out in the cold. 'Never again,' we said." ${ }^{32}$

Since the European public does not follow EU policies in general with much attention, there have only been rare instances of public reactions so far. ${ }^{33}$ But these documents and statements clearly suggest that reliance on Russian energy supply as such is a potential threat and Russia might even be inclined to use energy as a weapon in order to blackmail the EU. Accordingly, Russia is using a non-military threat to the sovereignty of the EU. The extent to which this threat is existential is key, in that it allows the breaking of contracts if necessary, because the Russians have forfeited the right to insist on the fulfillment of the contracts with the EU.

The Energy Union was finally enacted in February 2016. In contrast to the original proposal of President Tusk, its ultimate version was no longer focused on favoring the need for energy security, but rather placing

${ }^{30}$ European Commission, A Framework Strategy for a Resilient Energy Union with a Forward-Looking Climate Change Policy, p. 2.

${ }^{31}$ See remarks by EU High Representative/Vice-President Federica Mogherini at the Joint Press Conference ahead of the U.S.-E.U. Energy Council with U.S. Secretary of State John Kerry and U.S. Secretary of Energy Ernest Moniz, Washington, D.C., May 4, 2016, p. 2.

${ }^{32}$ Speech by Commissioner Miguel Arias Canete at the Security of Supply Package Press Conference, Brussels, February 16, 2016.

${ }^{33}$ Nick Butler, "The EU is Quietly Shaping Its Energy Union," Financial Times, April 13, 2015; and Bjoern Lomberg, "Nur Fracking hilft Europa gegen Putin's Gasmonopol," Die Welt, June 9, 2014. 
emphasis on "secure, sustainable, competitive, affordable energy for every European." ${ }^{34}$ Hence, among the five dimensions of the Union, "Energy security, solidarity and trust" is prioritized, followed by "A fully integrated energy market," "Energy efficiency," "Decarbonizing the economy" and interestingly enough, only as the last dimension, "Research, innovation and competitiveness." The last point is surprising in view of the EU's ambition to become the champion in renewable technology. ${ }^{35}$

\section{Natural Gas as a Controversial "Bridge Fuel"}

The Europeans have made it very clear that they would like to decrease their dependence on Russian gas deliveries as much as possible. As a compensation for the decrease of Russian gas supplies, the Energy Union offers a comprehensive diversification strategy focusing on natural gas. The Commission mentions explicitly the "Southern Gas Corridor," the set-up of LNG gas hubs and gas storage, as well as alternative gas suppliers such as the Mediterranean and Algeria. Thus, the securitization of Russian-EU gas trade is not at all triggered by an attempt to reduce gas as a main resource for the future. While the EU would only be obliged to buy Russian gas for another 13 years until 2029, the current EU diversification strategies are leading to a "lock-in" of gas as the future bridge even for the coming decades because they are requiring the construction of new infrastructure, such as LNG terminals plus gas storage and a new mega gas pipeline, as well as the Southern gas corridor.

Furthermore, shale gas is being approved with the expectation that the EU will renounce on a regulation of "fracked" shale gas. The communication on the "Energy Union" advertises the option of domestically produced energy as a means to contribute to a reduction of Europe's energy import dependence. This includes renewables as well as conventional sources and "for those Member States that choose it - non-conventional fossil resources - ...provided that issues of public acceptance and

${ }^{34}$ Press Release, “Energy Union: Secure, Sustainable, Competitive, Affordable Energy for Every European," European Commission, February 25, 2015, http://europa.eu/rapid/ press-release_ IP-15-4497_ en.htm; and Austvik, "The Energy Union and Security-of-GasSupply," pp. 372-382.

${ }^{35}$ Butler, "The EU is Quietly Shaping Its Energy Union." 
environmental impact are adequately addressed." ${ }^{36}$ It is important to note here that in 2014 the EU Commission renounced the opportunity to regulate shale gas extraction in a serious and comprehensive fashion and instead only issued minimal recommendations for taking care of the environmental damage of the "fracking." ${ }^{37}$

Initially, Europe's shale gas potential has been evaluated as substantial, but the numbers were downgraded. The IEA predicted in 2012 that there are more than 13 European countries with shale gas potential. ${ }^{38}$ Poland and France supposedly had the highest potential followed by Norway (not an EU member), Sweden, Denmark, and the United Kingdom. But Poland's reserves have been scaled back dramatically and turned into a non-issue in governmental circles. In any event, extraction of shale gas will be much more difficult than in the United States because of the higher density of the population and because most gas reserves are located 50 percent deeper in the ground than in the United States.

Shale gas is a controversial subject in the United States, and even more so in Europe. There is disagreement among European politicians and scientists as to how much shale gas contributes to a reduction of greenhouse gas emissions, as well as whether the environmental hazards of the "fracking" method could be curbed in a European business environment which is supposed to be more regulated than in the United States. So, why is hydraulic fracking so controversial with the potential to even undermine the climate action goals of the EU?

Serious environmental hazards and degradation result from shale gas extraction. Among them is an enormous depletion of water resources. According to Earthworks, 70 to 140 billion gallons of water ${ }^{39}$ are needed for 35,000 wells in the United States each year - this corresponds to the water consumption of 40 to 80 cities each with a population of 50,000. Fracking also requires the use of roughly 1,000 different chemical substances, several

${ }^{36}$ European Commission, A Framework Strategy for a Resilient Energy Union, p. 3.

${ }^{37}$ See Alexandra-Maria Bocse, "Transnational Policy Networks and the European Union's Energy Policy," Contemporary Politics, Vol. 21, No. 3 (2015), pp. 294-307.

${ }^{38}$ IEA, Golden Rules for a Golden Age of Gas (Paris: International Energy Agency, May 29, 2012), p. 120, http://www.worldenergyoutlook.org/media/weowebsite/2012/goldenrules/ WEO2012_GoldenRulesReport.pdf.

${ }^{39}$ This corresponds approximately to 151 to 265 billion liters of water. 
of them being carcinogenic ${ }^{40}$; it causes the contamination of ground water through these chemicals, ${ }^{41}$ competition with other activities for land use, traffic disruption and noise in communities, and even earthquakes. ${ }^{42}$ As noted by the IEA,

\begin{abstract}
Producing unconventional gas is an intensive industrial process, generally imposing a larger environmental footprint than conventional gas development... The scale of development can have major implications for local communities, land use and water resources. Serious hazards, including the potential for air pollution and for contamination of surface and groundwater, must be successfully addressed. ${ }^{43}$
\end{abstract}

Fracking plans and activities have led to intensive public debates. While shale gas production is being pushed by a lobbying alliance comprising international energy companies located in Brussels and those EU member states who had hoped or still hope to win economically by producing shale gas, it has been met with fierce public resistance in several of those EU countries where shale gas production was intended to take place. ${ }^{44}$ Five European countries had imposed bans or moratoriums on fracking: France, Bulgaria, the Netherlands, Luxembourg and the Czech Republic. In the UK, (sub)-national parliaments in Scotland and Wales have also introduced a fracking moratorium. The governments of Norway and Sweden found that exploiting their shale gas resources was not economically viable at the moment. It is difficult to predict when and where shale gas will be developed in Europe. Yet, gas companies are lobbying intensively in Brussels to

${ }^{40}$ Pascal Peduzzia and Ruth Hardinga, "Gas Fracking: Can We Safely Squeeze the Rocks?," United Nations Environment Programme, November 2012, https://na.unep.net/ geas/getUNEPPageWithArticleIDScript.php?article_id=93.

${ }^{41}$ Rob Jordan, "Stanford Researchers Show Fracking's Impact to Drinking Water Sources," Stanford News, March 29, 2016.

${ }^{42}$ Peduzzia and Hardinga, "Gas Fracking: Can We Safely Squeeze the Rocks?"

${ }^{43}$ IEA, Golden Rules for a Golden Age of Gas, p. 9.

${ }^{44}$ Tim Boersma, Energy Security and Natural Gas Markets in Europe: Lessons from the EU and the United States (London: Routledge, 2015). 
prevent the EU from seriously considering any kind of regulatory restrictions on fracking shale gas. ${ }^{45}$

\section{The EU will find it difficult to prioritize} natural gas as a main pillar of its energy strategy.

Nevertheless, shale gas is being promoted because of its perceived benefit toward climate mitigation. A large amount of greenhouse gases are produced when fossil fuels are burnt. The share of $\mathrm{CO}_{2}$ released when burning fossil fuels is the biggest for coal, followed by oil, and then by gas. In the United States, the fracking boom for gas is supported by the argument that gas is driving the dirty coal out of the market and is therefore good for climate change. Some coal plants in the United States have indeed been closed and the United States is exporting its coal to Europe to be burnt there. But it needs to be considered, that while gas emits around half as much $\mathrm{CO}_{2}$ as coal when burnt, it emits 10 times more than utility-scale solar, and even 45 times more than wind energy generated onshore. ${ }^{46}$ Thus, in terms of $\mathrm{CO}_{2}$ emissions, "an unrestricted gas boom could increase the use of the fuel by $170 \%$ by 2050," increasing overall $\mathrm{CO}_{2}$ emissions by 2 to 11 percent. ${ }^{47}$ But all these figures will pale in comparison if new research on methane is included into the picture. Gas consists mainly of methane. There are serious concerns that methane is leaking through the production and transportation of gas and increases its effect on climate change considerably. If it evaporates before being burnt, according to Scientific American, "[m]ethane warms the climate 86 times as much as carbon dioxide over a period of 20 years before breaking down in the atmosphere." 48

\footnotetext{
${ }^{45}$ Friends of the Earth Europe, Fracking Brussels: A Who's Who of the EU Shale Gas Lobby (Brussels: Friends of the Earth Europe, July 2014); and Bocse, "Transnational Policy Networks and the European Union's Energy Policy." For an overview of the opposition against fracking in Europe, see "What Ever Happened with Europe's Fracking Boom?," Deutsche Welle, June 26, 2014.

${ }^{46}$ Arthur Neslen, "BP Lobbied Against EU Support for Clean Energy to Favour Gas, Documents Reveal," Guardian, August 20, 2015, p. 3.

${ }^{47}$ Damian Carrington, "Fracking Boom Will Not Tackle Global Warning, Analysis Warns,"Guardian, October 15, 2014, p. 1.

${ }^{48}$ Bobby Magill, "EPA Will Regulate Methane Emissions from Oil and Gas Wells," Scientific American, May 13, 2016, p. 2.
} 
For a while, there have been suggestions that the extraction method of fracking in particular causes the leaking of greenhouse gas methane. It was alarming news when, on the basis of analyzed satellite data and surface observations, a 2016 Harvard study found a 30 percent increase in U.S. methane emissions over the 2002 to 2014 period, which accounts for "an enormous spike in methane in the entire planet's atmosphere." ${ }^{49}$ In this period the U.S. oil and gas production increased by 20 percent and the shale production nine times. ${ }^{50}$ Most of these methane emissions are attributed to oil and gas, but also to livestock, coal mining and waste. But the scientists also stress that at this point they cannot clearly point to the origin for the methane releases and that more research is needed to clearly identify the main source. Nonetheless, the releases that originate from gas production do very likely originate largely from unconventional rather than conventional production sites, because firstly, shale gas production necessitates the drilling of an enormous number of wells and, secondly, they are operated by smaller-sized companies with limited technologies. Therefore, "abundant gas may have a lot of benefits, such as economic growth, cutting coalrelated local air pollution and energy security... but slowing climate change is not one of them.." ${ }^{\prime 1}$

Another alternative source under discussion is to increase the current LNG supplies to the EU. The European Commission warns of the high costs of LNG, as the prices would be even higher than the gas imported from Russia. ${ }^{52}$ European consumers will not be ready to pay a "security premi$u^{\prime \prime 53}$ on LNG from the United States or Qatar in order to get rid of the dependence on Russian imported gas. In addition to lacking competitiveness, other technical problems exist. While European LNG terminals have

${ }^{49}$ Bill McKibben, "Global Warming's Terrifying New Chemistry," Nation, March 23, 2016.

${ }^{50}$ A. J. Turner, et al., "A Large Increase in U.S. Methane Emissions over the Past Decade Inferred from Satellite Data and Surface Observations," Geophysical Research Letter, 43, March 2, 2016, pp. 2218-2224.

${ }^{51}$ Carrington, "Fracking Boom Will Not Tackle Global Warning, Analysis Warns," p. 1.

${ }^{52}$ European Commission, Framework Strategy for a Resilient Energy Union, p. 2.

${ }^{53}$ Goldthau, "Addressing the Russian Energy Challenge: Why Regulations Trumps Geopolitics," p. 4. 
"ample spare capacity," 54 they are scattered in an asymmetrical manner across the continent, meaning new terminals will need to be built. For enhancing security of supply, the EU also launched a "Gas Package" which entails the intention to also build gas storage facilities. ${ }^{55}$ It is safe to conclude that all these infrastructure projects will "lock in" gas as the EU's primary resource for the decades to come. ${ }^{56}$

A last point that complicates the "gas bridge" is gas delivery. The EU has a history of failed plans for various gas pipeline projects bypassing Russia, intended to reduce its dependency on Russian gas and also to tap into the Central Asian gas potential. A project, which gained momentum as part of the Energy Union, is the Southern Gas Corridor. Originally, the Southern Gas Corridor did include Turkmenistan. This would have been an attractive option since the country has the world's sixth largest reserves (13.7 trillion cubic meters). But it seems that due to the unsettled legal status of the Caspian Sea, it will not be possible for Turkmenistan to join in the project. A partial version of the pipeline, reaching from Azerbaijan through Georgia and Turkey to Europe, is planned to become operational in 2019, transporting $10 \mathrm{bcm}$ gas per year. However, Azerbaijan's potential as the main feeder for the Southern Corridor is insufficient "to provide substantial supply diversification for Europe during the 2020s." ${ }^{157}$ Hence, we can expect strong EU efforts to tap into Turkmenistan's vast gas reserves in order to get a profit return on investment in this mega pipeline.

${ }^{54}$ Rafael Leal-Arcas, Juan Alemany Rios, and Constantino Grasso, "The European Union and Its Energy Security Challenges: Engagement through and within Networks," Contemporary Politics, Vol. 21, No. 3 (2015), pp. 273-293.

${ }^{55}$ European Commission, EU Strategy for Liquefied Natural Gas and Gas Storage, Communication from the Commission to the European Parliament, the Council, the European Economic and Social Committee and the Committee of the Regions, February 2, 2016.

${ }^{56}$ Stefan Boessner, "European Dash for Gas at Odds with Climate Ambitions," EnergyPost, March 13, 2016, http://energypost.eu/european-gas-strategy-clashes-climate-ambitions/; and Raines and Tomlinson, "Europe's Energy Union: Foreign Policy Implications for Energy Security, Climate and Competitiveness."

${ }^{57}$ Simon Pirani, "Azerbaijan's Gas Supply Squeeze and the Consequences for the Southern Corridor," Oxford Institute for Energy Studies, July 2016, p. 15, https://www. oxfordenergy.org/wpcms/wp-content/uploads/2016/07/Azerbaijans-gas-supply-squeezeand -the-consequences-for-the-Southern-Corridor-NG-110.pdf. 
In sum, a permissive approach to shale gas and a strong push to construct new infrastructure renders gas into Europe's new "bridge resource" until 2050 when Europe's economy is - according to the overarching climate goals - supposed to work in an almost decarbonized manner. The move towards natural gas is, however, highly controversial not only because Russia remains irreplaceable as the main gas import source, but also because gas is politically contested as new fossil infrastructure would create a "lock-in" that is highly environmentally unsustainable.

\section{A Strategic Moment for China after the Paris Agreement}

The EU's policy shift of putting all its eggs into the natural gas basket either produced through conventional or unconventional extraction methods offers some insights for Chinese policy makers. On one hand, China has very successfully diversified its energy import sources. ${ }^{58}$ On the other hand, China aims to restructure its energy mix and seems very committed to the COP 21 goals and a substantial reduction of its $\mathrm{CO}_{2}$ emission levels. China has two serious reasons to cut its $\mathrm{CO}_{2}$ emissions: it will not only be affected significantly by the effects of climate change, but the country also has to fight serious health issues related to air pollution. Outdoor pollution in China claims 1.6 million deaths a year. ${ }^{59}$ Much of the air pollution comes from the excessive burning of coal for power generation. According to the U.S. Energy Information Agency (EIA), "China produces and consumes almost as much coal as the rest of the world combined." ${ }^{60}$ Coal is responsible for two effects: $\mathrm{CO}_{2}$ emissions and the production of fine airborne particles less than 2.5 microns in diameter (PM 2.5) which penetrate the human body. This should be the most urgent policy goal - to reduce the 66 percent share of coal in the energy mix. But with 7.8 million people

${ }^{58}$ Maximilian Mayer and Jost Wübbeke, “Understanding China's International Energy Strategy," Chinese Journal of International Politics, Vol. 6, No. 3 (2013), pp. 273-298.

${ }^{59}$ Dan Levin, "Study Links Polluted Air in China to 1.6 Million Deaths a Year," New York Times, August 13, 2015.

${ }^{60}$ Joseph Ayoub, "China Produces and Consumes Almost as Much Coal as the Rest of the World Combined," U.S. Energy Information Administration, May 14, 2014, http://www. eia.gov/todayinenergy/detail.php?id=16271\&src=email. 
working in the coal sector, a quick reduction of the use of coal is domestically unfeasible to implement. The road to becoming sustainable was and is still a long one. ${ }^{61}$

At the moment, China's gas demand has dipped, only using 6 percent of total primary energy consumption. But it is expected to rise again. Under China's Energy Development Strategy Action Plan for 2014-2020, natural gas is targeted to make up at least 10 percent of energy consumption by 2020, with coal's percentage dropping from 66 percent to 62 percent. British Petroleum (BP) even estimates that by 2025 gas consumption will be as high as the consumption of the EU, roughly $400 \mathrm{bcm}$. Until 2008, China produced sufficient natural gas for its domestic consumption. Today, it has to import 31 percent of its consumption. China's supply includes LNG imports from various sources, but it is also planning to get an increasing volume from Russia through a new Russian gas pipeline expected to be operational by 2018. But there is international skepticism that this pipeline will be built in the projected time frame due to China's economic difficulties and low energy prices. ${ }^{62}$ Turkmenistan is the main source of pipeline gas for China, projected at $65 \mathrm{bcm}$ annually, which passes through Uzbekistan

China should be prudent about gas exploitation and take the opportunity to assume a leading role in global climate mitigation. and Kazakhstan.

As explained before, the EU has restructured its energy system in such a way that gas will play a dominant role in the next decades. It is to be expected that if legal problems connected to the transport through the Caspian Sea are resolved, Turkmenistan will join in the Southern Gas Corridor. With China's share of gas increasing in future it is expected that China will tap more of Turkmenistan's gas. Both the EU and China, as

${ }^{61}$ John Byrne, Bo Shen, and Li Xiuguo, “The Challenge of Sustainability: Balancing China's Energy, Economic and Environmental Goals," Energy Policy, Vol. 24, No. 5 (1996), pp. 455-462.

${ }^{62}$ Michael Ratner, Gabriel M. Nelson, and Susan V. Lawrence, “China's Natural Gas: Uncertainty for Markets," Congressional Research Service, May 2, 2016, p. 20, https://fas. org/sgp/crs/row/R44483.pdf. 
the most important energy importers of the world, must be prudent and avoid any kind of fierce competition for urgently needed resources.

According to the EIA, the shale potential of China is almost double that of the United States, but the geology of China's shale formations is very different. China's shale basins are found in difficult terrains, primarily in mountains, with the shale gas potential being hidden in depths ranging from 3,000 to 8,000 meters. This makes horizontal drilling particularly difficult, apart from setting up the pipelines and roads. ${ }^{63}$ Sinopec has started to drill in Fuling, a Yangtze River town, in Central China. ${ }^{64}$ Shale gas extraction will also turn out to be a problem for China because of the massive amounts of water required in the process. About 30 percent of China's river water is already highly polluted and therefore cannot be used for agricultural, industrial or electric purposes. Also, two-thirds of China's 660 cities suffer water shortages, 110 among them experience "severe" problems. ${ }^{65}$ Water pollution throughout the country sickens at least 190 million people and causes 60,000 premature deaths every year. ${ }^{66}$ Fracking to obtain shale gas is thus, as many Chinese experts have pointed out, not a sensible choice for China's future energy supply. Moreover, commercial fracking activities in China would likely need the technical support of U.S. companies to handle drilling several thousand meters deep underground into mountains. The U.S. government is already working to prepare the ground for U.S. energy companies to invest in China's energy sector.

The fact that the EU has shifted its emphasis from sustainability to energy security presents China with a unique strategic moment. At stake is not actually the potential rivalry over gas from Central Asia but rather the position of global climate leadership. Given the uncertainty of Donald Trump's climate policy, and the possible European fossil renaissance, China now has an opportunity to take on the role of global climate leader. By 2012, China had accounted for 24 percent of global greenhouse gas emissions,

${ }^{63}$ Anthony Fensom, “China: The Next Shale-Gas Superpower?," National Interest, October 9, 2014, http://nationalinterest.org/feature/china-the-next-shale-gas-superpower-11432.

${ }^{64}$ Brian Spegele, “Despite Global Glut, China Doubles Down on Natural Gas," Wall Street Journal, July 31, 2016.

${ }^{65}$ Elizabeth Economy, “The Great Leap Backward,"New York Times, August 24, 2007.

${ }^{66}$ Nathaniel Green and Matthew Kryman, "The Political Economy of China's Energy and Climate Paradox," Energy Research E Social Science, Vol. 4 (2014), p. 136. 
more than those of the EU and the United States combined, though on a per capita basis this still is much below the U.S. and European levels. China pledged that its greenhouse gas emission would peak in 2030 and later include only 20 percent fossil fuels in the energy mix. In terms of renewables, China is already a champion: including all hydro, renewables are supplying 27.5 percent of the country's electricity supply, twice as much as that of the United States. ${ }^{67}$ China already leads in investment in renewable energies. But to claim the global leadership role, China would have to do more than currently projected. It would need to reduce its coal consumption by a much higher percentage than planned, while reconsidering the accelerating export of coal-based technologies. ${ }^{68}$

\section{Conclusion}

The EU political establishment has engaged in an act of "securitizing" EURussian trade relations, portraying it as a non-military threat to the EU's sovereignty. While the objectivity of this threat cannot be evaluated, there are always intended and unintended consequences of this kind of "speech acts." One key consequence of these acts is the EU's diversification strategy that would lead to a locking-in of gas infrastructure for the decades to come. A further consequence might be the breakup of the energy monopoly of Gazprom in Europe as well as the triggering of the start of a new round of price negotiations with Gazprom. The second reason why the EU Commission appears committed to expanding the use of conventional and unconventional natural gas lies in lobbying efforts, which do partly contribute to the dynamic of securitization, but also follow a profit motive. As a result, gas is increasingly treated as "bridge fuel" until a carbon-free Europe can be accomplished by 2050. The new prominence of natural gas and its "securitization" could slow down renewable energy development in Europe. The reason is simply because the planned import, transport and storage infrastructure for natural gas and fracking investments have to be exploited to become economically viable. This path is not guaranteed. The

${ }^{67}$ Ibid.

${ }^{68}$ Beth Walker, "China Stokes Global Coal Growth," China Dialogue, September 23, 2016, https://www.chinadialogue.net/article/show/single/en/9264-China-stokes-global-coalgrowth. 
"rapid progress" made by renewables, both in term of capacities and costs, creates a growing dependence on gas. ${ }^{69}$ Yet, with the greenhouse gas emissions stemming from the production and transportation of methane, the EU has made a long-term commitment to a greenhouse killer that is more powerful than oil or coal. In turn, the combination of these factors paves the way for China to assume the role of the next global leader in climate mitigation. 